Jurnal Mahasiswa BK An-Nur : Berbeda, Bermakna, Mulia

Volume 4 Nomor 1 Tahun 2018

Tersedia Online: https://ojs.uniska-bjm.ac.id/index.php/AN-NUR

ISSN. 2460-9722

\title{
LAYANAN BIMBINGAN KELOMPOK UNTUK MENGURANGI KECEMASAN BERKOMUNIKASI PADA SISWA KELAS VIII MTS NURUL FALAH JUAI KABUPATEN BALANGAN
}

\author{
Yarah, Jarkawi, Farial \\ Universitas Islam Kalimantan Muhammad Arsyad Al-Banjari \\ yarah.bimbi@gmail.com
}

\begin{abstract}
ABSTRAK
Latar belakang penelitian ini didasari atas dasar perilaku siswa yang pasif dalam proses belajar mengajar seperti sulit mengemukakan pendapat, kurang mampu dalam berbicara didepan kelas, merasa cemas, gugup saat ingin bertanya dengan guru, ataupun persentasi dalam diskusi kelompok. Penelitian ini bertujuan untuk mengetahui perbandingan kecemasan berkomunikasi pada siswa kelas VIII di MTs Nurul Falah Juai kabupaten Balangan sebelum dan sesudah diberikan layanan bimbingan kelompok. Hipotesis dalam penelitian ini layanan bimbingan kelompok efektif mengurangi kecemasan berkomunikasi pada siswa kelas VIII MTs Nurul Falah Juai kabupaten Balangan. Populasi penelitian ini adalah siswa kelas VIII MTs Nurul Falah Juai tahun 2017. Sampel penelitian ini menggunakan teknik probabillty sampling dengan random sampling. Variabel yang digunakan yaitu layanan bimbingan kelompok sebagai variabel bebas dan kecemasan berkomunikasi sebagai variabel terikat. Uji validasi instumen menggunakan kolerasi item total terkoreksi, dan dilanjutkan uji reabilitas menggunakan rumus alpha. Hasil uji validitas instrumen diperoleh butir instrumen yang valid 60 butir dan 5 butir tidak valid digugurkan dengan koefisien reabilitas sebesar 0,947. Pengujian hipotesis menggunakan uji t. Hasil uji t menunjukan t-hitung $(-23,768)<\mathrm{t}$-tabel $(2,821)$. Dengan kata lain dapat dinyatakan hipotesis awal Ho ditolak yang berbunyi "tidak ada pengaruh layanan bimbingan kelompok dalam mengurangi kecemasan berkomunikasi pada siswa kelas VIII MTs Nurul Falah Juai kabupaten Balangan", sedangkan hipotesis kerja (Ha diterima) yang berbunyi "ada pengaruh layanan bimbingan kelompok dalam mengurangi kecemasan berkomunikasi pada siswa kelas VIII MTs Nurul Falah Juai kabupaten Balangan". Dengan demikian penelitian ini menyimpulkan bahwa hipotesis yang menyatakan "Layanan bimbingan kelompok efektif untuk mengurangi kecemasan berkomunikasi siswa kelas VIII MTs Nurul Falah Juai kabupaten Balangan", terbukti kebenarannya.
\end{abstract}

Kata Kunci : Layanan Bimbingan Kelompok; Kecemasan Berkomunikasi

\begin{abstract}
The background of this research is based on the perilku of passive students in the learning process such as difficult to express opinions, less able to speak in front of the class, feel anxious, nervous when want to ask with teacher, or presentation in group discussion. This study aims to determine the effectiveness of group guidance services to reduce communication anxiety in grade VIII students in MTs Nurul Falah Juai Balangan district. Hypothesis in this research of effective group guidance service to reduce communication anxiety to student of class VIII MTs Nurul Falah Juai Balangan district. The population of this study are students of class VIII MTs Nurul Falah Juai in 2017. The sample of this study using probabillty sampling technique with random sampling. The variables used are group guidance services as independent variables and anxiety communicate as dependent variable. The validation test of the instument uses correlated total item correlation, and continued the reliability test using the alpha formula. The instrument validity test results obtained by valid instrument grain 60 grains and 5 invalid grains were aborted with a coefficient of reliability of 0.947 . Hypothesis testing using $t$ test. Result of $t$ test shows $t$-count $(-23,768)<t$-table $(2,821)$. In other words, it can be stated that Ho's initial hypothesis is rejected which reads "there is no influence of group guidance service in reducing communication anxiety in grade VIII student MTs Nurul Falah Juai Balangan district", while the working hypothesis (Ha accepted) which read "there influence of guidance service group in Reduce communication anxiety in grade VIII students MTs Nurul Falah Juai Balangan district ". Thus this research concludes that the hypothesis which states "Service guidance group effective to reduce anxiety communicate class student of VIII MTs Nurul Falah Juai district Balangan", proven truth
\end{abstract}

Keywords: Group Guidance Services, Communication Anxiety

Dipublikasikan Oleh:

UPT Publikasi dan Pengelolaan Jurnal

Universitas Islam Kalimantan Muhammad Asyad Al-Banjarmasin 


\section{PENDAHULUAN}

Komunikasi merupakan hal yang penting dalam kehidupan manusia, komunikasi menyentuh segala aspek kehidupan manusia, tidak ada kegiatan yang dilakukan oleh manusia tanpa disertai dengan proses komunikasi. Begitu pentingnya komunikasi dalam kehidupan manusia, apabila mengalami hambatan dalam komunikasi akan mengalami permasalahan dalam kehidupan. Hambatan yang muncul dalam proses komunikasi yaitu timbulnya kecemasan dalam berkomunikasi.(dalam Aprianti, S, 2014: 1).

Dalam lingkungan sekolah peserta didik tidak hanya belajar untuk mencapai prestasi belajar, tetapi juga belajar untuk berinteraksi dan berkomunikasi dengan baik dengan teman sebaya, dewan guru dan semua personil disekolah maupun diluar disekolah. Bentuk komunikasi siswa yang dilakukan siswa dalam kelas seperti bertanya dengan guru, mempresentasikan tugas dan melakukan diskusi kelompok. (dalam Aswida, W, 2012:1).

Kenyataannya tidak semua peserta didik dapat lancar berkomunikasi. Ada beberapa hambatan yang dialami individu dalam berkomunikasi, seperti kecemasan berkomunikasi dalam proses belajar mengajar. Permasalahan kecemasan dalam berkomunikasi antara lain ketika guru memberikan kesempatan kepada peserta didik untuk mengemukakan pendapat, ide, atau gagasannya terhadap peserta didik terlihat takut, gugup, gelisah, bahkan sampai berkeringat dingin. Reaksi terjadi karena peserta didik beranggapan pendapatnya akan salah dan akan diremehkan oleh guru dan teman-temannya.(dalam Aprianti, S, 2014: 2)

Kecemasan berkomunikasi pada dasarnya merupakan gejala yang normal pada proses komunikasi, akan tetapi apabila kecemasan berkomunikasi tersebut berlebihan maka akan menjadi masalah yang serius. Ketidakmampuan individu berkomunikasi dapat menyebabkan komunikasi menjadi terhambat, dan akan membentuk individu menjadi pribadi yang pasif dan menghindari komunikasi. Adanya hambatan dalam komunikasi khususnya dalam proses pembelajaran tentu akan berpengaruh terhadap hasil komunikasi yang diperoleh. Hasil komunikasi dalam proses pembelajaran berupa pemahaman peserta didik terhadap materi yang diberikan oleh guru. Kecemasan komunikasi yang dialami peserta didik apabila tidak ditangani dapat membentuk pribadi yang pasif, sedangkan dalam proses pembelajaran di kelas peserta didik dituntut berperan aktif. Pasifnya peserta didik dalam berkomunikasi apabila terus dibiarkan akan
ISSN. 2460-9722

bepengaruh terhadap hasil belajar yang diperoleh oleh peserta didik. Peserta didik tidak dapat mengkomunikasikan ide, permasalah ataupun memberi umpan balik terhadap proses pembelajaran.(wahjudi,2009: 47)

Menurut Mc Croskey upaya yang dapat dilakukan dalam mengurangi kecemasan dalam berkomunikasi yaitu dengan layanan bimbingan kelompok. Layanan bimbingan kelompok merupakan salah satu teknik bimbingan dan konseling yang mempunyai dasar, kegiatan, sasaran dan tujuan dasar yang dilaksanakan dalam situasi kelompok, diberikan pada sekelompok individu didalam dinamika kelompok yang membahas masalah individu. Bimbingan kelompok dimaksudkan untuk mencegah berkembangnya masalah atau kesulitan diri pada konseli atau siswa. Isi kegiatan bimbingan kelompok terdiri atas penyampaian informasi untuk keperluan bagi para anggota kelompok.(Sutarti, dkk, 2013: 41)

Menurut Ifdil tujuan bimbingan kelompok secara umum adalah mengembangkan kepribadian siswa seperti kemampuan sosialisasinya, komunikasinya, kepribadian, kepercayaan diri, sehingga siswa dapat memecahkan sebuah masalah yang berlandaskan nilai ilmu dan agama. Menurut Ifdil tujuan bimbingan kelompok secara khusus adalah membahas topik yang mengandung masalah aktual, hangat dan menarik perhatian anggota kelompok. (dalam Sutarti, dkk, 2013: 42).

Kecemasan berkomunikasi pada siswa semakin diperjelas dengan kenyataan yang ada, melalui hasil observasi dan wawancara yang dilakukan peneliti di MTs Nurul Falah Juai, diketahui ada beberapa siswa yang pasif dalam proses belajar mengajar. Selanjutnya melalui pengalaman mengajar selama program PPL diperoleh hasil banyak siswa yang mengalami kecemassan berkomunikasi seperti sulit mengemukakan pendapat, pendiam, kurang mampu dalam berbicara didepan kelas. Guru mata pelajaran PKn dan B.indonesia juga mengungkapkan bahwa banyak siswa kelas VIII MTs Nurul Falah Juai yang merasa cemas, gugup, terbata-bata dalam menyampaikan pendapat, bertanya dengan guru, ataupun persentasi dalam diskusi kelompok. Berdasarkan uraian latar belakang diatas peneliti tertarik untuk melakukan penelitian dengan judul "Layanan Bimbingan Kelompok Untuk Mengurangi Kecemasan Berkomunikasi Pada Siswa Kelas VIII MTs Nurul Falah Juai".

Tujuan dari penelitan ini adalah untuk mengetahui bagaimana perbandingan kecemasan berkomunikasi siswa kelas VIII MTs Nurul Falah

Dipublikasikan Oleh:

UPT Publikasi dan Pengelolaan Jurnal

Universitas Islam Kalimantan Muhammad Asyad Al-Banjarmasin 
Juai sebelum dan sesudah diberikan layanan bimbingan kelompok.

\section{METODE}

\section{Populasi dan Sampel}

Populasi dalam penelitian ini adalah siswa kelas VIII MTs Nurul Falah Juai tahun 2017. Sampel penelitian ini menggunakan teknik probabillty sampling dengan random sampling.

\section{Teknik Pengumpulan Data}

Jenis penelitian yang digunakan dalam penelitian ini, yaitu penelitian kuantitatif. Penelitian dilakukan dua kali yaitu sebelum dan sesudah diberikan layanan bimbingan kelompok. Variabel dalam penelitian yaitu bimbingan kelompok sebagai variabel eksperimental, sedangkan variabel terikat terikatnya yaitu
ISSN. 2460-9722

kecemasan beromunikasi. Teknik pengumpulan data yang digunakan dalam penelitian ini adalah angket dan skala likert. Uji validitas data menggunakan analisis statistik kolerasi pearson product moment. Untuk menguji reliabilitas data menggunakan rumus alpha cronbach. Teknik analisis data dalam penelitian ini menggunakan analisis peired sample T-test menggunakan program SPSS versi 22.

\section{HASIL DAN PEMBAHASAN}

Dari hasil analisis data, diperoleh kecemasan berkomunikasi sebelum dan sesudah diberikan layanan bimbingan kelompok yang akan dipaparkan pada tabel 1 .

Tabel 1. Perbandingan kecemasan berkomunikasi siswa sebelum dan sesudah diberikan layanan bimbingan kelompok

\begin{tabular}{|l|c|c|c|c|c|}
\hline \multicolumn{3}{|c|}{ Pretest } & \multicolumn{2}{c|}{ Posttest } & \multirow{2}{*}{ Perbandingan } \\
\hline Nama & \%skor & kategori & \%skor & Kategori & 35 \\
\hline AY & 83 & $\mathrm{~T}$ & 48 & $\mathrm{R}$ & 27 \\
\hline ANS & 78 & $\mathrm{~T}$ & 51 & $\mathrm{R}$ & 27 \\
\hline JH & 75 & $\mathrm{~T}$ & 48 & $\mathrm{R}$ & 34 \\
\hline KN & 79 & $\mathrm{~T}$ & 45 & $\mathrm{R}$ & 33 \\
\hline MHD & 79 & $\mathrm{~T}$ & 46 & $\mathrm{R}$ & 37 \\
\hline MAD & 80 & $\mathrm{~T}$ & 43 & $\mathrm{R}$ & 32 \\
\hline MN & 84 & $\mathrm{~T}$ & 52 & $\mathrm{R}$ & 41 \\
\hline MS & 82 & $\mathrm{~T}$ & 41 & $\mathrm{R}$ & 30 \\
\hline NK & 85 & $\mathrm{ST}$ & 55 & $\mathrm{~S}$ & 36 \\
\hline PRN & 82 & $\mathrm{~T}$ & 46 & $\mathrm{R}$ & 33 \\
\hline $\begin{array}{l}\text { Rata- } \\
\text { rata }\end{array}$ & 81 & $\mathrm{~T}$ & 47 & $\mathrm{R}$ & $125 a n a n$ \\
\hline
\end{tabular}

Seperti tertera pada tabel 1, hasil perhitungan analisis deskriptif dapat diketahui bahwa sebelum diberikan layanan bimbingan kelompok kecemasan berkomunikasi dari 10 siswa terdapat seorang siswa yang memiliki kecemasan berkomunikasi sangat tinggi dengan dengan persentase $85 \%$ dan 9 orang siswa memiliki kecemasan berkomunikasi tinggi dengan persentase berkisar antara $75 \%$ sampai dengan $84 \%$. Hal ini menunjukkan dikelas VIII tingkat kecemasan berkomunikasi yang yang tinggi dengan persentase rata-rata $81 \%$.
Setelah diberikan layanan bimbingan kelompok kecemasan berkomunikasi pada siswa mengalami penurunan. Dapat dilihat perubahannya dari kategori tinggi dengan rata-rata persentase $81 \%$ menjadi rendah dengan rata-rata persentase $47 \%$, yang artinya mengalami penurunan sebesar $33 \%$. Jadi kecemasan berkomunikasi siswa dapat dikurangi melalui layanan bimbingan kelompok.

Sedangkan penurunan kecemasan berkomunikasi siswa pada setiap indikator sebelum dan sesudah diberikan layanan bimbingan kelompok dipaparkan pada tabel 2.

Tabel 2. Penurunan kecemasan berkomunikasi siswa tiap indikator sebelum dan sesudah diberikan layanan bimbingan kelompok.

\begin{tabular}{|l|c|c|c|c|c|}
\hline \multirow{2}{*}{ Aspek indikator } & \multicolumn{2}{c|}{ pretest } & \multicolumn{2}{c|}{ Posttest } & \multirow{2}{*}{ Penurunan } \\
\cline { 2 - 5 } & $\%$ skor & Kategori & \% skor & Kategori & \\
\hline Ketidaknyamanan internal & 65 & S & 48 & $\mathrm{R}$ & 17 \\
\hline Penghindaran & 68 & $\mathrm{~S}$ & 47 & $\mathrm{R}$ & 21 \\
\hline Penarikan diri & 77 & $\mathrm{~T}$ & 52 & $\mathrm{R}$ & 25 \\
\hline
\end{tabular}

Dipublikasikan Oleh: 
Tersedia Online: https://ojs.uniska-bjm.ac.id/index.php/AN-NUR

ISSN. 2460-9722

\begin{tabular}{|l|c|c|c|c|c|}
\hline Komunikasi berlebihan & 75 & $\mathrm{~T}$ & 43 & $\mathrm{R}$ & 32 \\
\hline Rata-rata & $71 \%$ & $\mathrm{~T}$ & $48 \%$ & $\mathrm{R}$ & $23 \%$ \\
\hline
\end{tabular}

Berdasarkan tabel 2, dapat diketahui bahwa semua indikator mengalami penurunan setelah diberikan layanan bimbingan kelompok. Dari setiap indikator kecemasan berkomunikasi tersebut, penururan yang terbesar yaitu indikator komunikasi berlebihan dengan persentase sebesar $32 \%$, disusul dengan aspek indikator penarikan diri persentase penurunan sebesar $25 \%$, selanjutnya aspek indikator penghindaran persentase penurunan sebesar $21 \%$, dan yang terakhir adalah aspek indikator ketidaknyaman internal persentase penurunan sebesar $17 \%$.

Layanan bimbingan kelompok berpengaruh dalam mengurangi kecemasan berkomunikasi pada siswa kelas VIII MTs Nurul Falah Juai, hal ini dapat dilihat dari hasil uji hepotesis T-test menunjukkan bahwa t-hitung ($23,768)<\mathrm{t}$-tabel $(2,821)$ maka hepotesis awal (Ho ditolak) dan Hepotesis kerja (Ha diterima).

\section{PENUTUP}

Kecemasan berkomunikasi pada siswa kelas VIII MTs Nurul Falah Juai Kabupaten Balangan sebelum diberikan layanan bimbingan kelompok berada pada kategori tinggi dengan persentase ratarata $81 \%$, sedangkan kecemasan berkomunikasi siswa sesudah diberikan layanan bimbingan kelompok berada pada kategori rendah dengan persentase rata-rata $47 \%$. Jadi. Kecemasan berkomunikasi siswa dapat dikurangi melalui layanan bimbingan kelompok karena mengalami penurunan yang cukup signifikan yaitu dengan perbandingan $33 \%$, sebelum dan sesudah diberikan layanan bimbingan kelompok . layanan bimbingan kelompok berpengaruh dalam mengurangi kecemasan berkomunikasi pada siswa kelas VIII MTs Nurul Falah Juai, hal ini dapat dilihat dari hasil uji hepotesis T-test menunjukkan bahwa thitung $(-23,768)<\mathrm{t}$-tabel $(2,821)$ maka hepotesis awal (Ho ditolak) dan Hepotesis kerja (Ha diterima).

\section{REFERENSI}

Arifin, Samsul B. 2015. Psikolosi Sosial. Jawa Barat: CV PUSTAKA SETIA

Apriyanti, Seli.2013. Efektivitas Teknik Restrukturisasi Kognitif Untuk Mereduksi Kecemasan Komunikasi Pada Remaja Tahun 2013. Skripsi Universitas Pendidikan Indonesia

Dipublikasikan Oleh:

UPT Publikasi dan Pengelolaan Jurnal

Universitas Islam Kalimantan Muhammad Asyad Al-Banjarmasin 
Jurnal Mahasiswa BK An-Nur : Berbeda, Bermakna, Mulia

Volume 4 Nomor 1 Tahun 2018

Tersedia Online: https://ojs.uniska-bjm.ac.id/index.php/AN-NUR

ISSN. 2460-9722

Sutarti, Masturi, dan Sucipto. 2013. Meningkatkan Kemampuan Beradaptasi Melalui Layanan Bimbingan Kelompok Siswa Kelas X MAN 2 Kudus. Vol 6, No.2 Hal40-47

Wahjudi, s.2009. Tingkat dan Faktor -faktor Kecemasan Komunikasi Mahasiswa dengan Dosen. Jurnal ilmu komunikasi. Hal 47-65

Zulfah, Nur Rosyida. 2016. Pengaruh Layanan Bimbingan Kelompok Dengan Teknik Role Playing Untuk Meningkatkan Minat Belajar Matematika Pada Siswa Kelas V Di SD Negeri Manggungan Kabupaten Banyumas Tahun Pelajaran 2015/2016. Skripsi Universitas Negeri Semarang 